\title{
Rare serious complications of erlotinib therapy
}

\author{
Shailendra Kapoor
}

Received: 21 November 2012 / Accepted: 13 December 2012 / Published online: 30 January 2013

(C) Springer-Verlag Wien 2013

To the editor:

I read with great interest the article by Alessandris et al. [1]. Interestingly, erlotinib may result in rare but fatal complications.

For instance, erlotinib may cause pulmonary complications. It may result in bronchiolitis obliterans and lung fibrosis [4]. Pneumonia may result because of these pulmonary changes [2]. Patients usually present with acute or sub-acute shortness of breath. Occasional deaths have been reported because of erlotinib-induced ARDS or respiratory failure [7].

Similarly, acute hepatitis and even acuter hepatic failure may occur because of erlotinib therapy [3]. Given this, liver function tests should be performed before initiating erlotinib therapy in carcinoma patients. Discontinuation of erlotinib therapy usually results in resolution of the acute hepatitis [6].

Vascular complications may also occur. For instance, superior vena cava syndrome has been reported following initiation of erlotinib therapy [5]. Patients may present with cyanosis and dyspnea. Thrombolytic therapy with agents such as streptokinase usually results in alleviation of the symptoms.

Other common side effects of erlotinib therapy include anemia, neutropenia and rashes. Rashes occur in $52 \%$ of patients. Thrombocytopenia may also occur. It is clear from the above example that erlotinib needs to be used carefully and patients should be monitored for these rare yet serious complications.
Conflicts of interest None.

\section{References}

1. D'Alessandris QG, Montano N, Cenci T, Martini M, Lauretti L, Bianchi F, Larocca LM, Maira G, Fernandez E, Pallini R (2012) Targeted therapy with bevacizumab and erlotinib tailored to the molecular profile of patients with recurrent glioblastoma. Preliminary experience. Acta Neurochir, Wien

2. Lind JS, Smit EF, Grunberg K, Senan S, Lagerwaard FJ (2008) Fatal interstitial lung disease after erlotinib for non-small cell lung cancer. J Thorac Oncol 3:1050-1053

3. Ramanarayanan J, Scarpace SL (2007) Acute drug induced hepatitis due to erlotinib. JOP 8:39-43

4. Ren S, Li Y, Li W, Zhao Z, Jin C, Zhang D (2012) Fatal asymmetric interstitial lung disease after erlotinib for lung cancer. Respiration $84: 431-435$

5. Salmi R, Gaudenzi P, Di Todaro F, Morandi P, Nielsen I, Manfredini $R$ (2007) Massive thrombosis of brachiocephalic veins and superior vena cava syndrome in a patient with non-small cell lung cancer treated with the epidermal growth factor receptor inhibitor erlotinib. Clin Drug Investig 27:499-503

6. Schacher-Kaufmann S, Pless M (2010) Acute fatal liver toxicity under erlotinib. Case Rep Oncol 3:182-188

7. Yoneda KY, Shelton DK, Beckett LA, Gandara DR (2007) Independent review of interstitial lung disease associated with death in TRIBUTE (paclitaxel and carboplatin with or without concurrent erlotinib) in advanced non-small cell lung cancer. J Thorac Oncol 2:537-543

S. Kapoor $(\bowtie)$

74 Crossing Place,

Mechanicsville, VA, USA

e-mail: shailendrakapoor@yahoo.com 